\title{
ERRATUM
}

Lawrence Que Jr.

\section{The heme paradigm revisited: alternative reaction pathways considered}

\section{J Biol Inorg Chem (2004) 9:643}

Due to an error at the typesetters, the print version and the online pdf version of this article were published with an old version of Scheme 1, whereas in the HTML version the scheme is correct. The correct version appears here.
Scheme 1

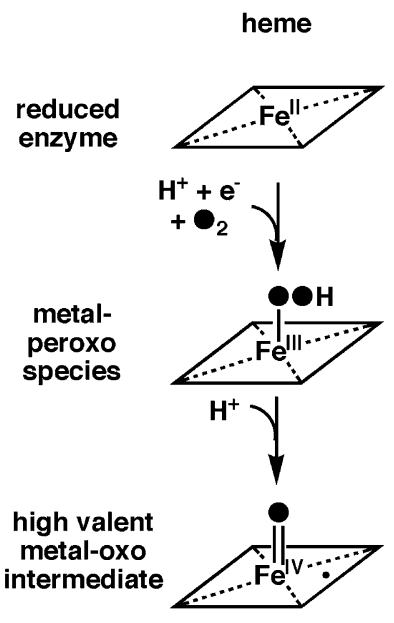

dicopper

nonheme diiron

nonheme monoiron<smiles>C[Al][Al](C)C</smiles><smiles>CC(C)CC(C)C</smiles>

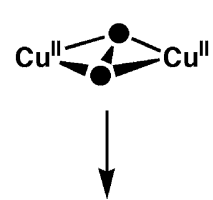<smiles>[AlH2][C@H]1C[C@@H]2C[C@H]1O2</smiles><smiles>CCCCCC(C)OC(C)OC(F)F</smiles>

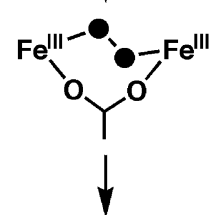

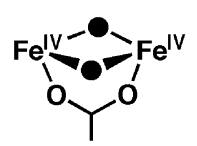<smiles>C=[Te]C</smiles>

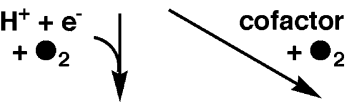

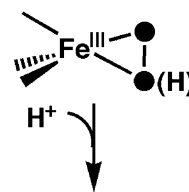

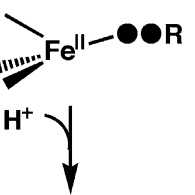<smiles></smiles>

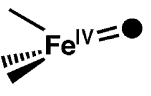

The online version of the original article can be found at http:// dx.doi.org/10.1007/s00775-004-0579-3

\section{Que Jr.}

Department of Chemistry and Center

for Metals in Biocatalysis,

University of Minnesota,

Minneapolis, MN 55455, USA

E-mail: que@chem.umn.edu

Tel.: + 1-612-6250389

Fax: + 1-612-6247029 